\title{
Socioeconomic Impact on Kampung Baru: Revisiting the Policy for the New Malaysia
}

\author{
SYAHMI @ MUHAMMAD SYAHMI JAAFAR \\ ADAM ABU HANIPAH \\ CHONG KA FOO
}

\begin{abstract}
The Kampung Baru represent a type of settlement that is unique to Peninsular Malaysia.This terms refer to villages built during the emergency as a military strategy under the Emergency Ordinance and also known as the Briggs Plan (1948-1960).The main aim of this article is to investigate the effects of development projects implementation on New Village at Peninsular Malaysia in Year 2017. In 2002, the Kajian Pelan Induk Kampung Baru (PIKB) was implemented under the designation of the Economic Planning Unit (EPU). PIKB's main objective is to integrate the new village in terms of physical, social, economic and political in the flow of state development. At the same time, taking into account the traditions, culture and historical value of Kampung Baru, strategies to perpetuate the features of Kampung Baru that have the potential to be developed as a tourist attraction are also taken. The objectives of this article are; to investigate the impact and effectiveness of construction of infrastructure, socioeconomics and landscaping facilities in Kampung Baru; to assess the level of satisfaction of the Kampung Baru residents towards the Kampung Baru development program which has been implemented; and to examine the problem of infrastructure, socioeconomics and landscaping facilities faced by the residents of Kampung Baru. After $9^{\text {th }}$ May 2018 seems the new dawn of Malaysia, the new Government may have a new policy in alleviating Kampung Baru to a new dimension. It is a hope that this article can give clear perspective and way forward on the socioeconomic impact of Kampung Baru with the new government policy.
\end{abstract}

Keywords: Kampong Baru, Socioeconomic, Government Policy, Development, Local Government

\section{INTRODUCTION}

The Kampung Baru terms refer to villages built during the emergency as a military strategy under the Emergency Ordinance and also known as the Briggs Plan (19481960). During this time, 382 of Kampung
Baru were developed while 48 existing villages were included in the program. The tabulation of Kampung Baru can be seen from the below diagram: 


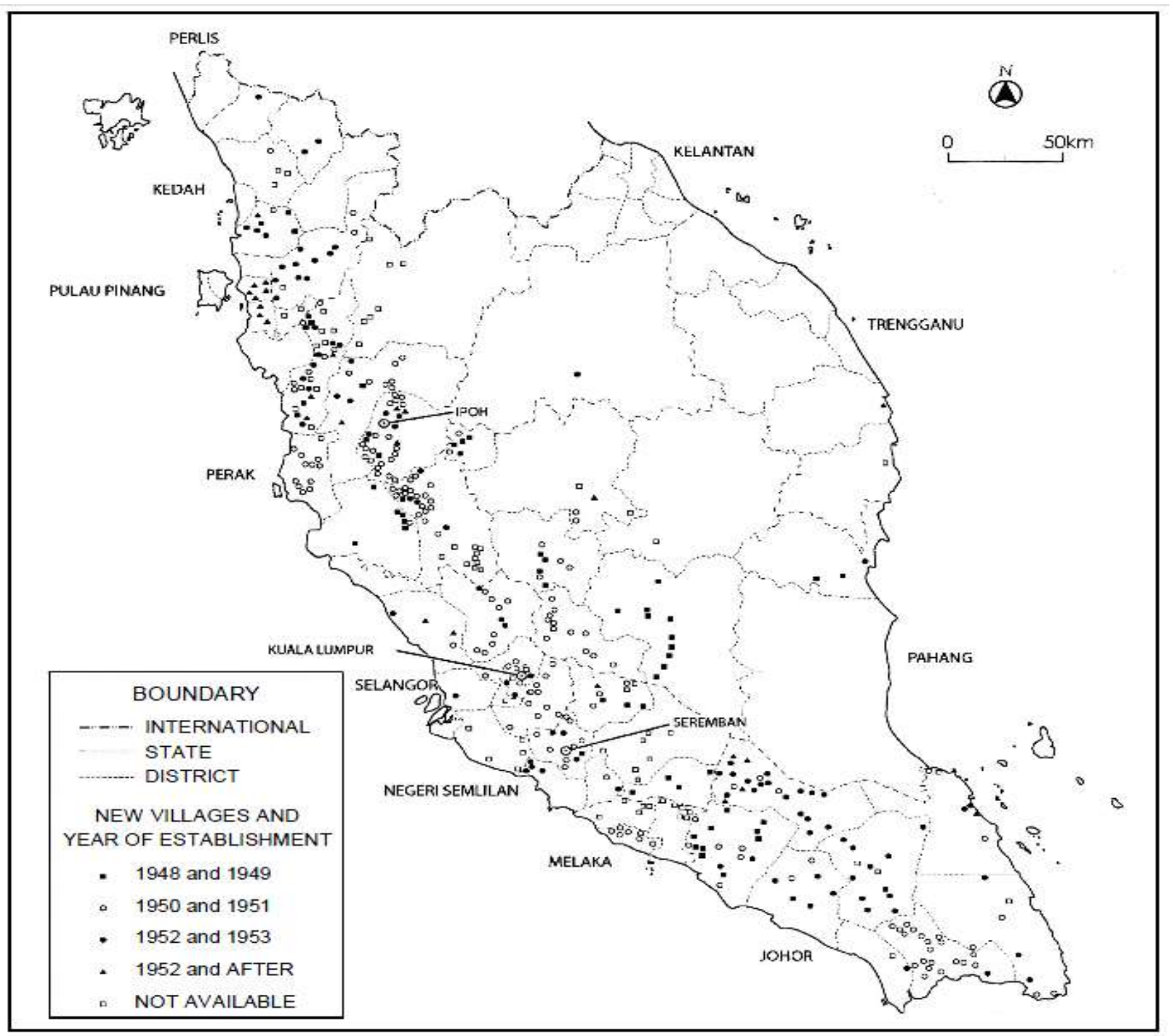

Fig. 1: Distribution of New Villages by Year of Establishment

The special origins of the Kampong Baru are attributed to a key strategy of the British colonial administration to re-assert political control over Malaya. One of the core military actions adopted was aimed at isolating the scattered and often armed anticolonial units. Hence a countrywide move was set in motion to "resettle" widely dispersed inhabitants in the rural areas. The targeted population was primarily the Chinese many of whom were identified in an official report as "squatters" who occupied state and private land ${ }^{1}$. The resettlement programme was "the gathering together under administration and protection of families who are, or may be, subject to bandit influence". 2 The word "bandit" was the official description for anti-colonial bands against whom the British administrators were waging an armed conflict to win the "hearts and minds" of the people.

Four basic aims were identified for the resettlement programme. These were to insulate the "Communist gunmen" from their main source of supply and to protect 
the squatters from coercion; to establish a degree of security that would give people the confidence to supply information about the enemies; to break up the cells and organizations of the enemies, and to force them to attack security forces on the latter's ground. ${ }^{3}$ In a hasty military operation, the colonial government succeeded in relocating half a million rural inhabitants into more than 400 compact villages between 1949 and 1954. ${ }^{4}$

Under the administration of the Ministry of Housing and Local Government (KPKT) the definition for Kampung Baru has been expanded to include the villages created after the emergency and have the aesthetic characteristics that must be maintained. The number of Kampung Baru has changed over time from 480 villages recorded in 1954 to 452 villages in 2005. The New Village Master Plan study has been conducted and found that the actual number of Kampung Baru throughout Peninsular Malaysia under the KPKT list is as much 450 village. Now, under the administration of Prime Minister's Department, the number of Kampung Baru increase to 613 villages (http://ekgbaru.jpm.gov.my).

In 2002, the Kajian Pelan Induk Kampung Baru (PIKB) was implemented under the designation of the Economic Planning Unit (EPU). PIKB's main objective is to integrate the new village in terms of physical, social, economic and political in the flow of state development. At the same time, taking into account the traditions, culture and historical value of Kampung Baru, strategies to perpetuate the features of Kampung Baru that have the potential to be developed as a tourist attraction are also taken.

Furthermore, the implementation of this study is a Key Performance Indicator (KPI) of YB Datuk Seri Ir. Dr. Wee KaSiong; the previous Minister in the Prime
Minister's Department which aiming at $80 \%$ achievement. $^{5}$ (Statistik Penggunaan Sub Modul SKT 2016 Bagi Jabatan Perdana Menteri, 2016)

\section{OBJECTIVE OF ARTICLE}

The main aim of this article paper is to investigate the effects of development projects implementation on New Village at Peninsular Malaysia which is started in Year 2017. The objectives of this study are to investigate the impact and effectiveness of construction of infrastructure, socioeconomics and landscaping facilities in Kampung Baru; to assess the level of satisfaction of the Kampung Baru residents towards the Kampung Baru development program which has been implemented; and to examine the problem of infrastructure, socioeconomics and landscaping facilities faced by the residents of Kampung Baru.

The above objective is pertinent to be reviewed due to the fact that if the project development whether a policy, program or project didn't achieves the goals set and benefits the target group or otherwise, it might ruin the project success. Project effectiveness maybe assessed by different interest groups - stockholders, managers, customers, employees and so on. Criteria for measuring project success must therefore reflect different views. ${ }^{6}$ Putting people first in development projects comes down to tailoring the design and implementation of projects to needs and capabilities of people who are supposed to benefit from them. ${ }^{7}$ Putting people first in development programs is no less an imperative now than before: in fact, it is even more readily recognized as the crucial requirement for inducing accelerated development. ${ }^{8}$

Similarly, different people, even if they are part of the same organization, will view success in different way at different times. No wonder that the notion of project 
success is so rarely agreed upon. 9 Therefore, this study will be the basis for the coordination and improvement of the program through Kampung Baru's resident feedback on implementation of the development project that has been implemented at all Kampung Baru in Peninsular Malaysia on year 2017. The scope of this study is to assess the impact of the implementation of small projects in the gotong-royong with the focus on project implementation under the provisions of the New Village Development. This study covers 613 of Kampung Baru throughout Peninsular Malaysia. ${ }^{10}$

\section{FACT FINDING OF THE ARTICLE}

Quantitative methodology will be adapted in this article. This is because quantitative methodology is suitable for this large sample of research as it tend to save time and money while collecting data. Plus, this method is convenience for respondents to answer the questions and collect the data needed for analysis. Primary data were collected through the distribution of questionnaires. This questionnaire survey covered the three areas, i.e. demographic info, project satisfaction feedback, suggestion on upcoming project.

First stage, questionnaires survey was conducted by distributed to the Chairman of the Village Security and Development Committee (JKKK) through the New Village Development Officer (PKP) to the people who are stakeholder for the New Villages which is the New Village residents. This survey group of people know well about their Kampung Baru as most of them were born and grew up there. This was a semi-structured questionnaire in which it included questions that allow locals to made recommendations, e.g. suggest priority of development such as built new road, upgrade drainage system or built multipurpose hall for the Kampung Baru. This survey was conducted within six months in year 2017, i.e. from April 2017 till October 2017. Among 1,839 questionnaire form distributed, 1,386 people were responded.

The second stage questionnaire survey was conducted via face to face interview in order to clarify the queries raised from first stage survey. It is an unstructured set of questionnaire aimed to find out the reason behind some of the responses in the first stage survey by the PKP and the Chairman of the JKKK randomly in its area. Respondents were selected among the residents of Kampung Baru but did not include JKKK members in order to ensure the feedback received was transparent and fair. For example, question was set in order to find out the reason in which the respondent gave a negative answer for the project development had done at Kampung Baru but a positive answer on the outcome of the project development. Subsequent to that, random site visit was conducted in order to observe the existing physical conditions and newly completed project development in Kampung Baru.

\section{BACKGROUND OF THE ARTICLE}

The history, growth and development of New Villages also known as Kampung Baru in Malaysia are common issues of discussion. The actions of relevant authorities to deal with the persistent problems of Kampung Baru have seldom been comprehensive and successful. Issues of politics, live ability and sustainability are discussed in relation to the future of Kampung Baru in this country. ${ }^{11}$ A recent study has revealed that some New Villages have prospered and others have stagnated. ${ }^{12}$ In essence, the New Villages that are located in the periphery of Kuala Lumpur and major 
towns have and will continue to progress in line with the economic development of the nation.

The New Villages situated outside small towns or in the midst of semi-rural areas tend to occupy the stagnant end of the development continue. Basically, it is the spill-over effects of the urbanization process that prompt the growth of the urban New Villages. These urban New Villages tend to be the sites of Small and Medium Industries (SMIs) and retail activities that normally complement the needs and requirements of the industries and economic functions of nearby urban centres. While the large urban centres stimulate the growth of surrounding New Villages, much also depends on the initiatives and efforts of the settlers themselves. 13 The article journal by Phang\& Tan, 2013 regarding Kampung Baru should not be viewed in isolation from the overall development of the country; neither should the development plans for the Kampung Baru, if any, ${ }^{14}$ be carried out based on an ad hoc basis which is the current practice is contradict statement because the previous Government have an office to manage Kampung Baru's welfare especially physical development known as BahagianKampung Baru (BKB) under Prime Minister's Department since year 2014. ${ }^{15}$

Before year 2014, BKB is under Local Government Department's management which is belonging to KPKT. The function of BKB is (1) develop the basic physical infrastructure at Kampung Baru and (2) provide assistance and support for Kampung Baru community social economic development in 613 Kampung Baru at Peninsular Malaysia. If Government isolate the Kampung Baru from the overall nation development, it won't have annual allocation or even allocation plan in $11^{\text {th }}$ Malaysia Plan (2016-2020). In this plan, the previous Government allocate RM426,050,000 for 5 years (Ministry of Finance, 2017) or RM85,210,000 annually as average as shown in Figure 1.

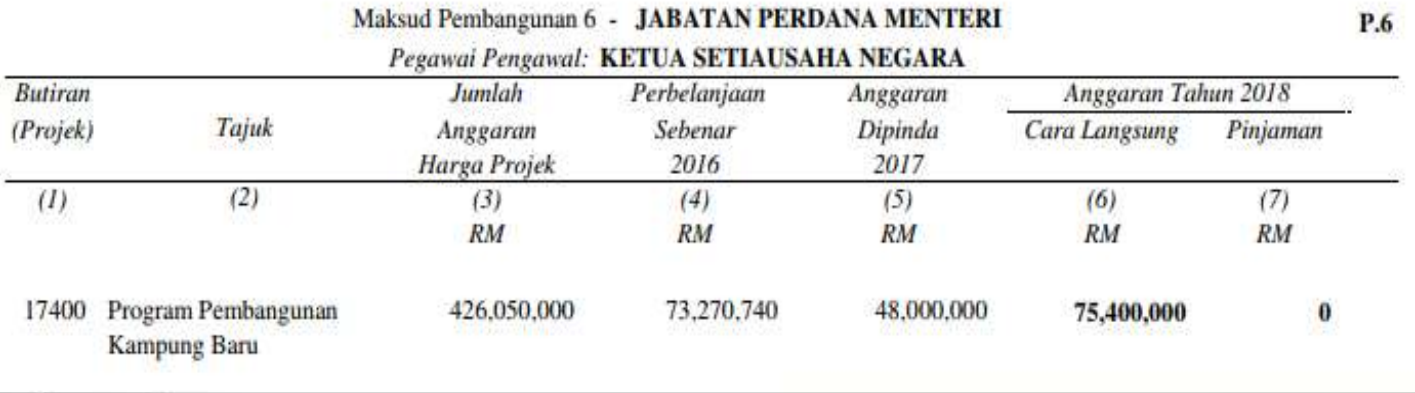

FIGURE 1. Development Program Allocation (Ministry of Finance, 2017)

\section{CHANGE OF POLICY FOR KAMPUNG BARU DEVELOPMENT}

In year 2005, KPKT conducted a master plan study of New Villages in Peninsular Malaysia to provide clear policy guidelines and strategies for their future development and growth. ${ }^{16}$ In this matter, Phang\& Tan, 2013 mention that KPKT had conducted a master plan study for these settlements in order to provide clear policy guidelines and strategies for their future developments and growth in 2005 . However till date there were no signs of any developments or with an 
average of RM100,000 per settlement per year revealed the insufficient government funding for these New Villages. ${ }^{17}$ Furthermore this financial allocation was neither statutory mandate nor consistent as it mostly affected by the political influences.

The study provided by Tin \& Lee in year 2017 is contradict in terms of figure and facts which the average allocation for 613 Kampung Baru is RM139,004 annually for each in The Eleventh Malaysia Plan, $2016-2020{ }^{18}$ Beside of that, the previous Prime Minister of Malaysia and Finance Minister, YAB Dato' Sri MohdNajib bin Tun Abdul Razak giving a 2018 Budget speech in Parliament on $27^{\text {th }}$ October 2017 to table the Bill intituled "An Act to apply a sum from the Consolidated Fund for the service of the year 2018 and to appropriate that sum for the service of that year" mention at point number 147.

Furthermore, to develop Chinese New Villages, a total of RM65 million is provided, while another RM10 million for housing refurbishment programme. ${ }^{19}$ and Figure 2 shown thatdevelopment allocation for year 2018 is RM75,400,000 which mean that each Kampung Baru will have allocation approximately RM123,000.

\section{TOUCHPOINTS BAET 2018}

28. Kesejahteraan Masyarakat Cina dan India

$\checkmark$ Pinjaman PKS melalui Koperasi Jayadiri Malaysia Berhad (KOJADI): (RM50j)

$\checkmark$ Yayasan Peniaga dan Penjaja Kecil 1Malaysia untuk komuniti Cina: (RM30j)

$\checkmark$ Pembangunan Kampung-kampung Baru Cina dan pembaikan rumah: (RM75j)

$\checkmark$ Skim Pembangunan Usahawan Masyarakat India melalui TEKUN

$\checkmark$ Pengagihan khas unit tambahan Amanah Saham 1Malaysia untuk masyarakat India:

(RM1.5b)

$\checkmark$ Mengambilan kaum india ke IPTA dan Penjawat Awam baharu ditingkatkan 7\%

FIGURE 2. Touch Points 2018 Budget (Prime Minister's Office, 2017)

\section{ANALYSIS AND FINDINGS}

Statistical Package for Social Science (SPSS) software will be used to analyses the data collected. Analysis and tests such as Frequency test, Cronbach's Alpha tests, One-way ANOVA test, Independent T-test and Pearson's correlation test will be applied to analyses the data collected.Based on the study conducted, the problems faced by the villagers are as follows:

1. Flood;

2. Absence of recreational facilities;

3. Agricultural land;

4. Land ownership;
5. Road damaged;

6. Drainage damaged; and

7. Lack of Community Places.

The most significant problem faced by the villagers is the drainage $(65.15 \%)$, the roads are damaged $(59.91 \%)$, the absence of recreational facilities $(47.49 \%)$, agricultural land problems (46.58\%) and land ownership $(42.37 \%)$. Flood problems $(38.52 \%)$ and lack of community places $(18.45 \%)$ were less significant. Figure 4 shows Kampung Baru resident's feedback on the problems encountered. 


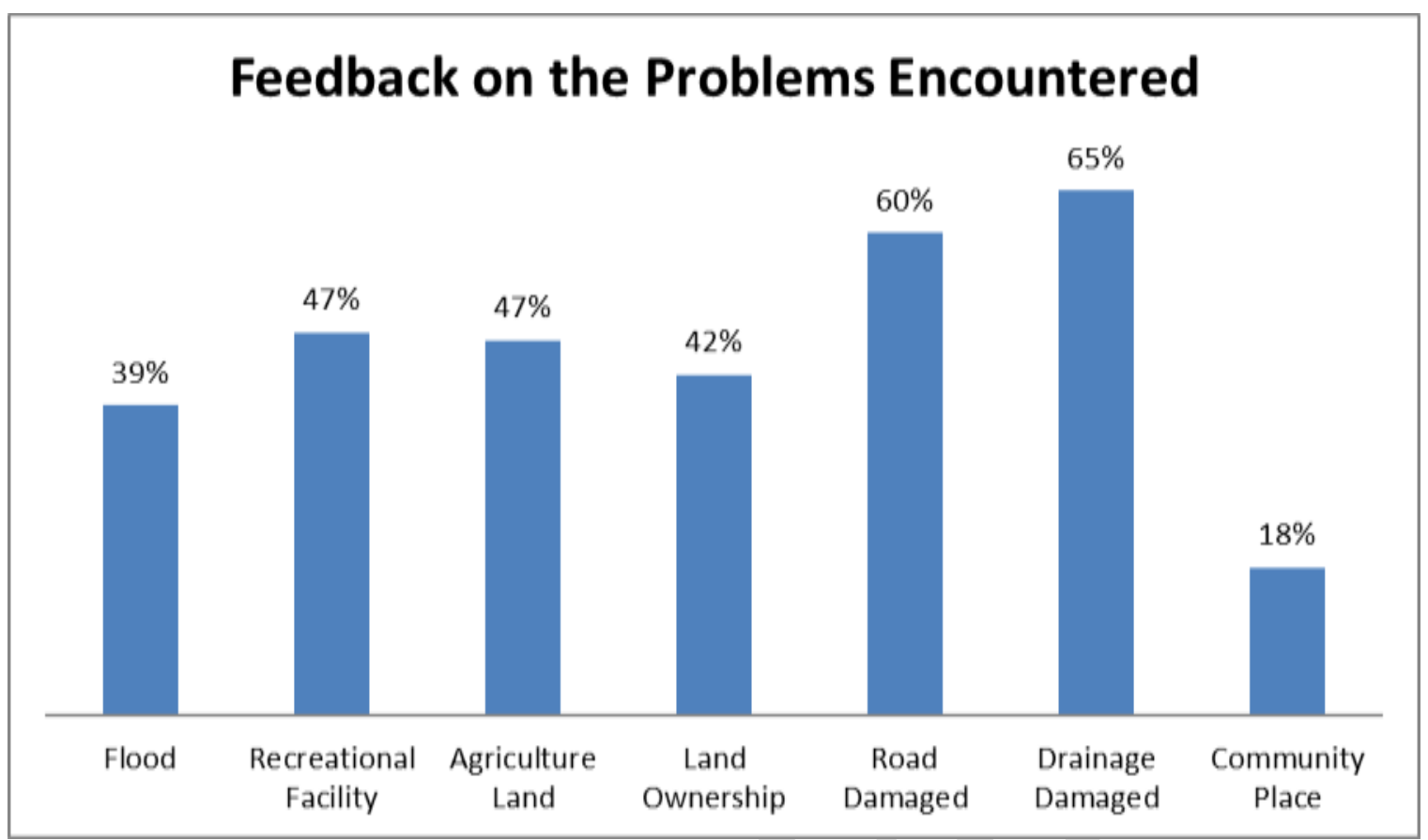

FIGURE 3. Kampung Baru Resident's Feedback on the Problems Encountered

Based on the findings of the study, it was found that the main problems faced by the villagers were drainage, road damage, lack of recreation areas, agricultural land problems, land ownership problems, lack of communities and floods. Problems (except land problems) arise as most of these villages are not fully assisted by Local Authorities in terms of infrastructure planning and development as well as socioeconomic facilities.

Demographics of Respondents
Accordingly, in the planning of infrastructure projects and socio-economic facilities, it is proposed that the following considerations be considered such as (1) the focus of the implementation of the village development project, (2) increasing number of systematic and high quality drainage and recreational facilities and (3) increasing systematic and complete development system to solve not only problem of drainage but also flood problem. 
TABLE 1. Genders of Respondents

\begin{tabular}{lcc}
\hline Gender & Frequency & Percentage (\%) \\
\hline Male & 1,033 & 74.50 \\
\hline Female & 353 & 25.50 \\
\hline
\end{tabular}

TABLE 2. Ages of Respondents

\begin{tabular}{lcc}
\hline Age & Frequency & Percentage $(\%)$ \\
\hline $20-29$ years old & 83 & 6.00 \\
\hline $30-39$ years old & 152 & 11.00 \\
\hline $40-49$ years old & 416 & 30.00 \\
\hline $50-59$ years old & 360 & 26.00 \\
\hline More than 60 years old & 374 & 27.00 \\
\hline
\end{tabular}

TABLE 3. Academic Qualifications of Respondents

\begin{tabular}{lcc}
\hline Academic Qualification & Frequency & Percentage (\%) \\
\hline None & 83 & 6.00 \\
\hline Primary & 444 & 32.00 \\
\hline Secondary & 651 & 47.00 \\
\hline STPM/Cerificate/Diploma & 144 & 10.40 \\
\hline Degree/PhD & 55 & 4.00 \\
\hline Others Academic Qualification & 8 & 0.60 \\
\hline
\end{tabular}

TABLE 4. Professions of Respondents

\begin{tabular}{lcc}
\hline Profession & Frequency & Percentage (\%) \\
\hline Government Sector & 69 & 5.00 \\
\hline Private Sector & 222 & 16.00 \\
\hline Retired & 249 & 18.00 \\
\hline Farmer & 222 & 16.00 \\
\hline Labour & 139 & 10.00 \\
\hline Fisherman & 42 & 3.00 \\
\hline Entrepreneur & 333 & 24.00 \\
\hline Others & 111 & 8.00 \\
\hline
\end{tabular}


TABLE 5. Satisfaction on Infrastructure Development Effect

\begin{tabular}{lcc}
\hline Satisfaction Level & Frequency & Percentage (\%) \\
\hline Very Satisfied & 116 & 8.39 \\
\hline Satisfied & 678 & 48.89 \\
\hline Neutral & 451 & 32.52 \\
\hline Not Satisfied & 121 & 8.73 \\
\hline Not Very Satisfied & 19 & 1.37 \\
\hline
\end{tabular}

TABLE 6. Satisfaction on Socio-Economic Development Effect

\begin{tabular}{lcc}
\hline Satisfaction Level & Frequency & Percentage (\%) \\
\hline Very Satisfied & 149 & 8.10 \\
\hline Satisfied & 485 & 35.01 \\
\hline Neutral & 668 & 36.37 \\
\hline Not Satisfied & 231 & 16.65 \\
\hline Not Very Satisfied & 52 & 3.76 \\
\hline
\end{tabular}

TABLE 7. Satisfaction on Landscaping Facilities Development Effect

\begin{tabular}{lcc}
\hline Satisfaction Level & Frequency & Percentage (\%) \\
\hline Very Satisfied & 86 & 4.68 \\
\hline Satisfied & 408 & 29.45 \\
\hline Neutral & 551 & 39.73 \\
\hline Not Satisfied & 278 & 20.09 \\
\hline Not Very Satisfied & 84 & 6.05 \\
\hline
\end{tabular}

\section{WAY FORWARD: NEW GOVERNMENT WITH THE NEW POLICY}

May $9^{\text {th }} 2018$ seems the new dawn in Malaysia with the change of new government after a shock general election result. The new Government may have a new policy in alleviating Kampung Baru to a new dimension. With this notion, a further detailed study is to be recommended to identify satisfaction level of Kampung Baru residents in order to ensure effectiveness of project development will be able to benefit the entire nation despite their socioeconomy background. Interview shall be extending to all Kampung Baru in Malaysia in order to gain more detailed results on effectiveness of project development. Future study can include the revision on current questionnaire survey form. Second, this study did not look at geography differences such as on island, seaside, riverside, urban, sub-urban, rural and hill which location of Kampung Baru may influence the needs and wants on the type of project development.

Third, future research effort should consider the effect of project development by parliament constitution or state constitution as study done by Phang \& Tan, 2013 on Parliament of Selayang. Fourth, future study should analyse the practise of other countries such as Hong Kong, Taiwan, Macau, Singapore or China. After more than half a century of development and the 
success in making "better use" of the potentials of Kampong Baru, it will benefit the village community, previous government and other relevant parties if they recognize that these villages can be an active participant in national development beyond their pertinent role as a catalyst in the Malaysia strive for sovereignty. In sum these countries have different approaches in project development for residents due to their different politic background and society formation.

\section{NOTES}

1 Newboult, A.T. et al. Report of Committee Appointed by His Excellency the High Commissioner to Investigate the Squatter Problem , Kuala Lumpur: Government Press, 1949..

2 Webber, M. L. Resettlement, (1951) 14, Malayan Forester, 155-157

3 Stead, Ronald The "New Villages" in Malaya, (1955) 27 Geographical Magazine, 642-652.

4 Dobby, E.H.G. 1952/53. Resettlement transforms Malaya: a case-history of relocating the population of an Asian plural society, Economic Development and Cultural Change, 1: 163-189.

5 JabatanPerdanaMenteri. 2016. StatistikPenggunaan Sub Modul SKT 2016 Bagi Jabatan Perdana Menteri. Retrieved from http://www.jpm.gov.my

/jpm2/sites/default/files/hrmis/SKT\%2004082016 .pdf

6 Stuckenbruck, L.CWho determines project success?, (1986) Proceedings of the 18th Annual Seminar/Symposium (Montreal/Canada), 85-93. Upper Darby, PA: Project Management Institute

7 Sergio Sepúlveda G., Sustainable Development: Social Organization, Institutional Arrangements and Rural Development, 1997, pp. 209

8 Michael M. Cernea, 1985. Putting People First: Sociological Variables in Rural Development, pp. xii

9 Shenhar, A., \&Dvir, D. Reinventing project management: The diamond approach to successful growth and innovation. Boston, MA: Harvard Business Press, 2007.

10 Jabatan Perdana Menteri. Statistik Penggunaan Sub Modul SKT 2016 Bagi Jabatan Perdana Menteri. Retrieved from http://www.jpm.gov.my/jpm2 /sites/default/files/hrmis/SKT\%2004082016.pdf
11 Phang SiewNooi\& TAN Teck Hong, 2013. New Village's in Malaysia: Living Conditions and Political Trends. Malaysian Journal of Chinese Studies, pp. 17-27

12 Voon PhinKeong, The Chinese New Village's in Malaysia: Impact of demographic changes and response strategies, (2009) 12, Journal of Malaysia Chinese Studies, 73-105

13 Ministry of Housing and Local Government New, Village's Master Plan Peninsular Malaysia. Kuala Lumpur: Government Printer, 2005.

14 Phang SiewNooi\& TAN Teck Hong, 2013. New Village's in Malaysia: Living Conditions and Political Trends. Malaysian Journal of Chinese Studies, pp. 17-27

15 Laman Web RasmiBahagianKampung Baru JabatanPerdanaMenteri. 2017. PelanStrategik BKB 2016 - 2020. Retrieved from http://ekgbaru.jpm.gov.my/sites/default/files/flipp ingbook/pelan\%20strategik\%20bkb\%2020162020/index.html

16 Ministry of Housing and Local Government 2005. New Village's Master Plan Peninsular Malaysia. Kuala Lumpur: Government Printer

17 Wan Jiun Tin \&Seok Hwan Lee, Development of neighborhood renewal in Malaysia through case study for middle income households in New Village Jinjang, Kuala Lumpur. Sustainable Cities and Society, 2017, 191-201

18 Economic Planning Unit (EPU), The Eleventh Malaysia Plan (2016 - 2020), 2017. Retrieved from http://epu.gov.my/en/rmk/eleventh-malay sia-plan-2016-2020

19 The Star Online. 2017. Budget 2018 Full Speech. Retrieved from https://www.thestar.com.my/new s/nation/2017/10/27/budget-2018-full-speech/

\section{REFERENCES}

Cernea, M. M. 1985. Putting People First: Sociological Variables in Rural Development, pp. xii

Dobby, E. H. G. 1952/53. Resettlement transforms Malaya: A case-history of relocating the population of an Asian plural society, Economic Development and Cultural Change, 1: 163-189.

Economic Planning Unit (EPU). 2015. The Eleventh Malaysia Plan (2016 - 2020). Putrajaya: Government Printer.

Economic Planning Unit (EPU). 2017. The Eleventh Malaysia Plan (2016 - 2020) 
Retrieved from http://epu.gov.my/en/r k/eleventh-malaysia-plan-2016-2020.

Government Transformation Programme (GTP): The Roadmap. Chapter 12: Enchancing Accountability with Ministerial KPIs. Retrieved from http://gtp.pemandu.gov.my/gtp/upload /6ea810f0-4276-43ba-b3c719eed2aa3346.pdf.

Jabatan Perdana Menteri. 2016. Statistik Penggunaan Sub Modul SKT 2016 Bagi Jabatan Perdana Menteri. Retrieved from http://www.jpm.gov.my/jpm2/sites/def ault/files/hrmis/SKT\%2004082016.pd f.

Kementerian Kewangan. 2017. Bajet 2018. Retrieved from http://www.treasury. gov.my/pdf/bajet/maklumat_bajet_ker ajaan/2018/B.6.pdf.

Laman Web Rasmi Bahagian Kampung Baru Jabatan Perdana Menteri. 2017. Sejarah Kampung Baru. Retrieved from

http://ekgbaru.jpm.gov.my/content/sej arah-kampung-baru

Laman Web Rasmi Bahagian Kampung Baru Jabatan Perdana Menteri. 2017. Pelan Strategik BKB 2016 - 2020. Retrieved from http://ekgbaru.jpm.g ov.my/sites/default/files/flippingbook/ pelan\%20strategik\%20bkb\%2020162020/index.html.

Ministry of Housing and Local Government 2005. New Village's Master Plan Peninsular Malaysia. Kuala Lumpur: Government Printer

Newboult, A. T. et al. 1949. Report of Committee Appointed by His Excellency the High Commissioner to Investigate the Squatter Problem. Kuala Lumpur: Government Press.

Phang Siew Nooi \& Tan Teck Hong, 2013. New village's in Malaysia: Living conditions and political trends.
Malaysian Journal of Chinese Studies: 17-27.

Prime Minister's Office. 2017. Touch Point Bajet 2018. Retrieved from https://www.pmo.gov.my/bajet2018/T ouchpointBajet2018.pdf.

Project Management Institute. 2013. A guide to the project management body of knowledge $\quad\left(P M B O K^{\circledR}\right.$ Guide $) . \quad 5^{\text {th }}$ edition. Newtown Square, PA: Author.

Sergio Sepúlveda, G. 1997. Sustainable Development: Social Organization, Institutional Arrangements and Rural Development, pp. 209.

Serrador, P. \& Turner, R. 2015. The relationship between project success and project efficiency. Project Management Journal, 46(1), 3039. Retrieved from http://dx.doi.org/10.1002/pmj.21468

Shenhar, A. \& Dvir, D. 2007. Reinventing Project Management: The Diamond Approach to Successful Growth And Innovation. Boston, MA: Harvard Business Press.

Shenhar, A. J., Levy, O. and DovDvir. 1997. Mapping the dimensions of project success. Project Management Journal 28(2): $5-13$.

Stead, R. 1955. The "New Villages" in Malaya. Geographical Magazine 27: 642-652.

Tavakol, M. and Dennick, R. 2011. Making Sense of Cronbach's Alpha. International Journal of Medical Education 2:53-55 Editorial.

The Star Online. 2017. Budget 2018 Full Speech. Retrieved from https://www. thestar.com.my/news/nation/2017/10/2 7/budget-2018-full-speech/

Voon Phin Keong. 2009. The Chinese New Village's in Malaysia: Impact of demographic changes and response strategies. Journal of Malaysia Chinese Studies 12: 73-105 
Voon PhinKe ong and Khoo Soo Hock 1986. The new villages in Peninsular Malaysia. Malaysian Journal of Tropical Geography 14: 36-55.

Wan Jiun Tin \& Seok Hwan Lee. 2017. Development of neighborhood renewal in Malaysia through case study for middle income households in New Village Jinjang, Kuala Lumpur. Sustainable Cities and Society 32: 191-201

Webber, M. L. 1951. Resettlement. Malayan Forester 14: 155-157

Syahmi @ Muhammad Syahmi Jaafar

Pengarah Visa Pas Permit

Jabatan Imigresen Malaysia

Putrajaya, Malaysia

Email:syahmijaafararimi@gmail.com

Adam Abu Hanipah

Pengarah Bahagian Khidmat Pengurusan

Jabatan Penilaian dan Perkhidmatan Harta

Malaysia (JPPH)

Kementerian Kewangan Malaysia

Putrajaya, Malaysia

Email:adam@jpph.gov.my

Chong Ka Foo

Kementerian Pertanian Malaysia

Putrajaya, Malaysia

Email:kafoo@moa.gov.my 